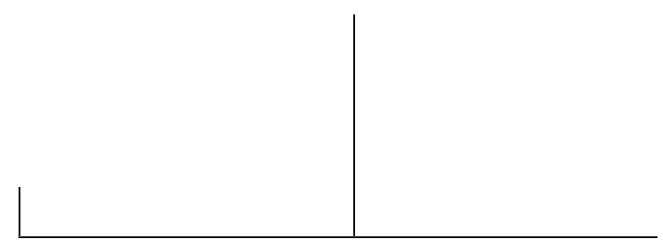

Rev. Latinoam. Psicopat. Fund., São Paulo, 16(1), 154-156, mar. 2013

Anatomia da melancolia. Vol. II - A Primeira Partição - Causas da melancolia Robert Burton Curitiba: Editora UFPR, 2012, 538 págs.

\title{
Anatomia da melancolia - A primeira partição - Causas da melancolia
}

Roberto Kirschbaum

Ao bater os olhos no volume II da edição brasileira da Anatomia da melancolia, de Robert Burton, o leitor se depara com "A sinopse da primeira partição", um diagrama em árvore que, ao explicitar as seções, membros e subseções em que este tomo se divide, percorre espantosas sete páginas, sendo que o ramo mais longo se estende por 16 níveis. Este diagrama ilustra visualmente a vastidão do terreno coberto por Burton. Se quisermos, ilustra sua obsessividade que, aliada a uma grande curiosidade, pode ser considerada como qualidade num autor psicopatólogo.

Esta "Primeira Partição" cuida das causas da melancolia. Burton começa pelo começo, localizando no mito edênico, no paraíso perdido, a origem primeira das misérias do homem e suas causas. O caminho que ele percorre é hipertextual, não linear: da Bíblia vai para o mito de Pandora, volta para outra parte da Bíblia, pula para o naturalista romano Plínio (23-79), fala dos índices de mortalidade em 
algumas cidades da Terra, e então traz novamente outra citação bíblica, menciona o dramaturgo romano Plauto (230-180 a.C.), Santo Agostinho (bispo, escritor, teólogo, filósofo, 354-430), o poeta épico Homero (séc. VIII a.C. est.), enfim vai tecendo uma rica trama, elencando e correlacionando as fontes internas e externas da desgraça e sofrimento humanos. Em certos pontos mostra uma capacidade de insight psicopatológico notável: quando relaciona, por exemplo, a "nossa facilidade e propensão em ceder a vários prazeres, em acatarmos toda paixão" (Burton, 2012, p. 23) ao surgimento de doenças, podemos traduzir, em termos psicanalíticos atuais, em "uma mente em que o princípio do prazer comanda, em desequilíbrio com o princípio da realidade, é uma mente doente". A ideia de excessos de prazeres e paixões como fonte de doença também nos remete à oralidade, à sexualidade oral e aos seus excessos, isto é, aos distúrbios da oralidade - manifestações da melancolia - como a anorexia, a bulimia, e adicções em geral.

Em seguida, cuida da definição, número e divisão das doenças. Citando dentre muitos outros o médico e filósofo romano Galeno (ca. 129-ca. 199 ou 217), Virgílio (poeta romano clássico, 70 a.C.-19 a.C.), Paracelso (médico, alquimista, físico e astrólogo suíço, 1493-1541), Hesíodo (poeta grego contemporâneo a Homero), considera várias formas de classificar as doenças como fazem os médicos: agudas e crônicas, primárias e secundárias, letais, salutares etc etc. Por fim, diz que em seu próprio sistema classificatório há apenas duas categorias: "doenças do corpo e da mente". Generoso, antes de partir para falar das doenças da mente, dá ao leitor não menos de 18 referências na medicina para as doenças em geral. Das doenças da mente menciona as principais? "frenesi, loucura, melancolia e delírio", e declara que seu alvo principal é a melancolia. Continua, indo do geral para o particular, diferenciando loucura, frenesi e melancolia. Depois, diferencia "melancolia por disposição", que seriam as melancolias transitórias, do dia-a-dia, decorrentes de dissabores e frustrações que a todos acometem, da doença propriamente chamada de melancolia. Aqui, uma palavra de aviso aos que desejariam a cura definitiva das melancolias transitórias: "Ninguém pode se curar; mesmo os deuses têm amargas pontadas e paixões frequentes" (Burton, 2012, p. 33). É no entanto a forma mais crônica da doença que ele considera propriamente a melancolia, e é sobre esta que dedicará a maior parte de sua atenção no resto do volume.

À medida em que vai lendo e se entretendo com a erudição coloquial de Burton, o leitor pode em certo momento se perguntar onde é que este quer chegar. Mas de certa forma o objetivo de Burton é mais o percurso em si do que o destino final. E sobre esse percurso, seu texto, pode-se dizer que é feito de associações livres, milhares delas. Assim, séculos antes da invenção da "cura pela fala" o autor da Anatomia já se utilizaria de um método parecido, neste caso, uma "cura 
pela escrita”: “(...) escrevo sobre melancolia, pois me ocupo para afastar a melancolia" (Burton, 2011, p. 60). Se pensarmos na ênfase que Freud dá, em sua descrição do quadro melancolia, ao empobrecimento do ego, podemos supor que ao ligar e articular seus inúmeros fragmentos de conhecimento (só este volume II conta com 1.963 notas, ou seja, 123 páginas só de notas), Burton vai construindo sentido, enriquecendo seu ego e cuidando de sua melancolia. Que o ego do leitor possa sair igualmente enriquecido desta leitura.

\section{Referências}

Burton, R. (2011). Anatomia da melancolia (v. I). Curitiba: Editora UFPR.

Burton, R. (2012). Anatomia da melancolia (v. II). Curitiba: Editora UFPR.

Freud, S. (2011). Luto e melancolia. In Luto e melancolia. São Paulo: Cosac \& Naify. (Trabalho original publicado em 1917).

Wikipédia. A enciclopédia livre. Recuperado de: 〈http://pt.wikipedia.org〉.

\section{Roberto Kirschbaum}

Psicólogo e psicanalista; Mestrando pelo Programa de Estudos Pós-Graduados em Psicologia Clínica da Pontifícia Universidade Católica de São Paulo - PUC-SP (São Paulo, SP, Br) sob orientação do Prof. Dr. Manoel Tosta Berlinck; bolsista do Conselho Nacional de Desenvolvimento Científico e Tecnológico - CNPq (Brasília, DF, Br)

Rua Veríssimo Glória, 165

01251-140 São Paulo, SP, Br

Fone: (11) 92935-8310

e-mail: robertokir@gmail.com 